\title{
Synching and swimming naturally on the side - the translation of hesitation in dubbing
}

\author{
Pablo Romero Fresco \\ Heriot-Watt University
}

The traditional consideration of audiovisual translation (AVT) as constrained translation has brought about, in the particular case of dubbing, a great deal of research on the different synchronies at play in this type of translation to the detriment of other equally essential issues such as the naturalness of dubbed dialogue. The aim of this study is to analyse the use of hesitation markers in dubbing in order to look precisely at the naturalness of dubbed dialogue while taking into account the audiovisual constraints. This analysis is carried out by comparing the dubbed dialogue (English-Spanish) of a popular American sitcom to the non-translated but prefabricated dialogue of a Spanish sitcom and finally to spontaneous conversation in Spanish. It is suggested that an approach focusing on the specificity of AVT rather than on its constraints enables not only the analysis of naturalness in dubbed dialogue but also the consideration of factors that can be as revealing as the audiovisual constraints, namely audiovisual leeway.

\section{Introduction: the neglected study of the naturalness of dubbed dia- logue}

As far back, at least by the standards of audiovisual translation (AVT), as 1973, Lorna Myers wrote a short article describing the conflict between naturalness and synchrony at play in dubbing, that is, the conflict resulting from having to produce natural-sounding dialogue while adhering to the constraints posed by the different synchronies existing in this type of translation. Focusing on the United States, Myers (1973: 58) criticised the adoption by the American audiences and professionals of the "sync or swim" approach, whereby all attention is given to synchrony, often resulting in the occurrence of unnatural dubbese in dubbed scripts. More than thirty years later, much has been done in the field of AVT, but this issue is still very much at the core of both practice and research on dubbing, as proved by Gottlieb's (2006) identification of naturalness and synchrony as the two main conventions of this type of translation. However, looking at what has been written during this period, it becomes clear that these two conventions have received very different treatment in AVT research. Whereas the label constrained translation, applied initially to subtitling (Titford 1982) and then more generally to AVT (Mayoral et al. 1988) has brought about a great 
deal of attention to dubbing synchronies, the naturalness of dubbed dialogue has been largely neglected in spite of its recognised importance.

Recently, and following Herbst's (1987) early attempt to tackle this issue in the case of the German dubbing language, some scholars such as Pavesi (2005) in Italian and Chaume (forthcoming) in Spanish have carried out corpus-based studies that are beginning to bridge what is still an inexplicably wide gap. The present article may be regarded as a further contribution in this respect with regard to the Spanish dubbing language.

\section{Aims and definitions}

Given the broadness of the subject and the limited space available, this study will focus exclusively on a very recurrent phenomenon in conversation, namely hesitation, and more specifically on discourse markers (DMs) used to convey it. The aim is, as has already been stated, to analyse the naturalness of the Spanish dubbing language and to ascertain the influence that AVT constraints or, more specifically, dubbing constraints, may have on this issue.

Naturalness is regarded in this study as a synonym of idiomaticity, albeit not in the traditional sense of "given to or marked by the use of idioms" (Onions 1964: 952). Instead, the notion of idiomaticity called upon here refers to "[the use of language that] sounds natural to native speakers of that language" (Sinclair 1995: 833). It is also important to note that rather than focusing on what is correct or grammatically possible, naturalness/idiomaticity alludes in this case to what is conventional among the many grammatically possible choices (Warren 2004: 5). Thus, drawing on Pawley and Syder (1983) and especially on Warren (2004: 1), naturalness is defined as the "nativelike selection of expression" that involves "knowing which particular combinations are conventional in a language community although other combinations are conceivable".

\section{Corpora, methodology and some key premises}

Revolving as it does around the notions of conventionality and frequency, this study relies heavily upon the use of three corpora.

- $\quad$ A parallel corpus consisting of transcripts (therefore post-synchronised) of 48 episodes of the American TV series Friends (ST) and their dubbed versions in Spanish (TT): 300,000 words approximately. Friends is one of the most successful series of all time and, in many ways, the quintessential sitcom, featuring realistic dialogue that is designed to sound believable and spontaneous (Nye et al. 2005).

- $\quad$ A corpus made up of 26 episodes (one season) of the Spanish sitcom Siete vidas (SV): 150,000 words approximately. Siete Vidas is the first 
and so far most successful sitcom produced in Spain and is clearly inspired by Friends in terms of characters, plots, settings etc. (Huerta 2005).

- $\quad$ The spontaneous speech section of the Spanish corpus CREA, elaborated by the Real Academia Española, featuring approximately 12 million words.

The idea is to assess the naturalness of the TT (translated and fictional) by comparing it to the language used in Siete Vidas (non translated and fictional) and to the language used in CREA (non-translated and non-fictional, i.e. spontaneous) ${ }^{1}$. This comparison operates under three basic premises. The first one is that placing the focus on the specificity of AVT provides a wider scope for research than placing it on its constraints. To mention one advantage, this new focus allows to add the naturalness of the dubbed dialogue to the equation as well as to consider dubbing constraints under a new light. The second premise is that, given its slippery nature, naturalness is best tackled in as empirically a way as possible. In other words, a comparison between a ST and a TT plus the native judgement of the researcher do not suffice to provide objective insights into the naturalness of the TT. It is thus necessary to resort to empirical data about the source and especially the target language, both theoretical (studies on colloquial conversation) and practical (corpora of naturally-occurring conversations). In this sense, the combination in the present study of AVT and conversational DMs, two fields that have experienced a similar boom within Translation Studies and Linguistics in the past decade, may yield interesting results for both disciplines. Finally, the third premise has to do with the methodology used for the analysis of the corpora and their comparability. Indeed, in order to draw a comparison between them, the differences need to be established first and then borne in mind throughout the study. These differences do not only include audiovisual constraints, but also, for example, those related to the elaboration of fictional dialogue. Only when all these differences have been taken into account can the comparison between the corpora be objectively carried out.

\section{Differences to be considered in the comparative analysis of the cor- pora}

This section deals briefly with those factors that characterise the language used in the TT by opposition to that of SV and especially to CREA, albeit that, for the sake of brevity, they are not discussed in detail ${ }^{2}$.

The first factor that may have an impact on the naturalness of the TT derives from the ST. As a fictional script, the ST is not spontaneous but rather, from the point of view of its mode, "written to be spoken as if not written" (Gregory and Carroll 1978: 42). Yet, a careful look at the elaboration process of a sitcom script such as the one analysed here reveals that its prefabricated nature originates before it is written. As a matter of fact, an average episode of Friends is planned for half a month by ten to fifteen au- 
thors before the dialogue is actually written over ten to fifteen days and finally acted and produced in the next fifteen to twenty days (Kelly 2003). More accurately then, the ST may be regarded as planned to be written and to eventually be acted as if not written or planned. More importantly, this initial plan determines to a great extent the naturalness of the dialogue. It is a sort of straightjacket featuring the constraints that characterise fictional scripts as well as those of sitcom dialogue.

Among the constraints posed by fictional scripts, the most relevant ones are:

- $\quad$ the polyfunctionality of the dialogue (Pfister 2001), i.e., the fact that they are addressed to both the characters (diegetic level) and the audience (extradiegetic level);

- the fact that "every linguistic unit - including phenomena of dysfluency and error" must fulfil a function in the "overall communicative goal of the dramatic dialogue" (Baumgarten 2005: 86).

As for the features of sitcom dialogue, in the particular case of Friends they have to do with:

- the plots: there are usually three in every episode;

- the characters: there are six main characters, all of whom have to appear and play an important part in every episode;

- $\quad$ the settings: except for two or three minutes in every episode, most scenes are shot in the same familiar settings or "centres of action" (Mayhew Archer 2005);

- the duration: 21-22 minutes with a break of 7-8 minutes before which a cliff-hanger is often needed;

- the need to fulfil a comic purpose, which is why $80 \%$ of the scenes end up on a punch line or a comic climax stressed by the sound of canned laughter.

Taking into account that, despite all these constraints, sitcom dialogue is supposed to sound idiomatic and spontaneous (Berger 1990), it may thus be described as straightjacketed dialogue that is intended to sound natural.

The other two characterising factors that are worth-mentioning in this section are related to the TT. The first one has to do with the constraints posed by dubbing. These constraints will be tackled in the qualitative analysis of the present study making use of Chaume's model (2004a) for the analysis of audiovisual texts from a translational viewpoint. This model regards the audiovisual text as a semiotic construct whose meaning, transmitted through the acoustic and the visual channels, is produced by the interaction of different audiovisual codes. The focus of this model is placed on the specificity of AVT, namely the interaction of audiovisual codes that may bring about instances of constraints but also leeway, thus sitting perfectly with the premises mentioned above. As for the dubbing constraints, 
namely the different synchronies, Chaume explains that in Spain the norm is that lip-synchrony, including the translation of labial and bilabial sounds, is only taken into consideration in close-ups. Otherwise, only isochrony (similar length of ST and TT utterances) and kinetic synchrony (synchrony between utterances and movements or gestures) apply. This is indeed the case in the 48 episodes of Friends analysed here, which feature only four close-ups, none of which contains a DM.

Finally, the last factor to be taken into consideration is the prefabricated orality of the TT. Also straightjacketed dialogue that is intended to sound natural, the TT dialogue must abide by a number of linguistic conventions that are specific to the Spanish dubbing language and that may have an impact on the naturalness of the TT (Chaume 2004a). However, these conventions, accounted for in the linguistic code of Chaume's model (2004a:167 et seq.), are not always an obstacle for the translator. In the case of discourse markers, for example, most guidelines recommend the use of these units to achieve a natural-sounding dialogue (Chaume forthcoming).

Once the main differences between the corpora have been specified, an objective comparison can be attempted. Before this, however, the next section describes the DMs analysed in this study, with special attention to their importance and relevance in fictional and naturally-occurring corpora.

\section{Hesitation and (self-)repair markers}

When engaged in spontaneous conversation, speakers often find themselves hesitating (Baumgarten 2005) or replacing and refining expressions as they go along (Brown and Yule 1983). The impromptu nature of conversation brings about a number of features that are not included in traditional descriptions of the language and that are described by Biber et al. (1999) as performance phenomena, which include false starts, repeats, restarts, lengthenings, self-corrections and pauses (Biber et al. 1999, Leech and Svartik 1994). Although the examples included in this study will certainly feature all these elements, the focus will be placed only on the last two (self-corrections and pauses), given the essential role played by hesitation and (self-)repair markers (HRMs) in their production.

Described by Brown and Yule (1983: 15) as "pre-fabricated planning 'fillers", HRMs tend to be used unconsciously and are more or less void of semantic content (Cortés Rodríguez 1991). It is precisely this lack of semantic content, as well as the fact that they are often used in combination with filled and/or unfilled pauses, that has gained them an unfair reputation as superfluous empty words (Porroche Ballesteros 1996) or even as the reflection of a bad habit on the part of the user (Stenström 2006). However, most scholars seem to agree nowadays that, even in their capacity as fillers, HRMs fulfil an essential role in colloquial conversation. In situations in which the real-time conditions of spontaneous conversation are espe- 
cially pressing, HRMs such as well and you know help the speaker to hold his/her turn while planning the next intervention (Christl 1996). They are thus considered both as turnholders and planning devices (Stenström 2006). As such, they can be used by speakers who want to go on speaking (Cortés Rodríguez 1991) but also as stallers (Lam 2006) or delay devices (Fuller 2003), when speakers need time to stop and think while hesitating. Likewise, they fulfil a repair function in that they help speakers to adjust what they have said (Lee and Hsieh 2004) if they "struggle for words" (Coates 1996: 152).

Apart from the above-mentioned well and you know, other HRMs in English are I mean (Fox and Schrock 2002) and like (Meehan 1991). In Spanish, bueno, o sea and pues are also very common and often posited as possible translations (Chaume 2004b, Stenström 2006), although a one-toone correspondence can hardly be expected here. In any case, there seems to be little doubt as to the crucial role played by these and other DMs in spontaneous conversation (Fox and Schrock 2002) as well as in fictional dialogue (Mattsson 2007), where their main function is usually to provide dialogue with a "naturalistic conversational effect" (Lee and Hsieh 2004).

Having described the main characteristics of HRMs, the next section offers an account of the Spanish HRMs analysed in this article. Indeed, given that the aim of this study is to analyse the naturalness of the TT, the focus will be placed initially on the Spanish markers, although both the ST units triggering them and dubbing constraints will be taken into consideration.

\section{The Spanish HRMs analysed in this study}

\subsection{Bueno}

This is one of the most common DMs in colloquial conversation in Spanish (Martín and Portolés 1999). As a HRM, bueno allows speakers to correct and reformulate their own discourse (Lindqvist 2005). It is often suggested as the most common and straightforward translation for well, and, in general, as a fairly transparent DM in terms of meaning, which may help to explain why it is one of the first DMs to be used (and overused) by nonnative speakers of Spanish (Lindqvist 2005).

\subsection{O sea}

Apart from being a marker of consequence or conclusion (Martín and Portolés 1999), o sea is an extremely recurrent HRM with an added sociological value that has led Briz (1998:212; my translation) to label the current generation of young Spanish people as the "o sea generation". It provides time for speakers to think and hold their turn, supporting them in their hesitation (Cortés Rodríguez 1991) and, according to Schwenter (1996:864), 
marking their "ongoing thought processes" as they organise and prepare their next utterance. Schwenter also notes a number of regularities in the use of this marker - it tends to occur in medial position and with "first person singular subjects and belief verbs" (Scwenter 1996:864). Needless to say, the different nuances attached to $o$ sea make it difficult to find one-toone correspondences in other languages, hence its scarce and problematic use among non-native speakers (Lindqvist 2005).

\subsection{Pues}

Although its functions are manifold and more varied than those of $o$ sea, Martín and Portolés (1999: 4083) make a clear distinction between the role of pues as a connector (indicating either cause or consequence) and its role as a sentence-initial 'commentator' in colloquial conversation, where it introduces content regarded by the speaker as particularly valuable and relevant to what has been said before. However, except for some specific cases, this sentence-initial pues does not indicate hesitation. In this sense, what is relevant to this study is the use of the 'commentator' pues in sentencemedial position, where it is often preceded or followed by pauses (Stenström 2006) and enables speakers to hold their turn as they struggle to formulate and reformulate their discourse (Briz 1998). As it happens with $o$ sea, pues is one of the last DMs to be acquired by non-native speakers, probably due to the low correlation between form and meaning (Lindqvist 2005).

\subsection{Vamos}

As an independent, (semi)lexicalised unit (i.e. not as a verb), vamos can function as an interjection or a conversational DM (Romero Aguilera 2006). The interjection is the first non-literal use of vamos and the most common one in colloquial conversation, where it serves as a stimulant (Vigara Tauste 1992) to persuade the addressee to do something (Hernández García 1997). When fulfilling its more specialised role as a HRM, it allows speakers to search for the right expression, while at the same time showing signs of cooperation and complicity with the hearer. According to Martín and Portolés (1999), this complicity comes from the original features of vamos as a verb, given that it is used with first person plural subjects and therefore includes both the speaker and the hearer.

\subsection{Es que}

In essence, es que is a copulative structure with an omitted subject (Lindqvist 2005). However, its common occurrence in spoken language, especially among young people (España Villasante 1996: 129), as a lexicalised unit and always in the present, has earned it the status of DM (1996:134). As such, its pragmatic function is to introduce justification or 
explanation in the discourse (Porroche Ballesteros 1998). In instances of hesitation and (self-)repair, it is usually found in sentence-medial position as a strategy to buy time to think during the on-line production of spontaneous discourse (España Villasante 1996:139). It still fulfils the pragmatic function of justification, but it occurs in a context of hesitation along with other performance phenomena such as repeats and false starts. Unlike pues and $o$ sea, es que seems to pose no problems for non-native speakers, who, if anything, and as it happens with bueno, tend to overuse it (Lindqvist 2005).

\subsection{Claro and hombre}

The role of claro and hombre as HRMs is marginal as compared to their role as epistemic and interactive markers respectively (Martín and Portolés 1999). However, when used in hesitation, they are useful muletillas or supports for the speaker. Unlike pues, they do not usually introduce long pauses, whether filled or unfilled, and, especially in the case of hombre (and probably due to its origin as a vocative), they carry a friendly connotation that makes them suitable for colloquial conversation (Martín and Portolés 1999: 4172). Finally, another feature of these two markers (which also applies to es que) is that they tend to co-occur with connectors indicating cause, consequence or objection such as porque, $y$ and pero.

\section{Quantitative and qualitative analysis of all HRMs}

Table 1: HRMs in the three corpora*

\begin{tabular}{|c|c|c|c|}
\hline HRM & TT & SV & CREA \\
\hline Bueno & 64 & 49 & 232 \\
\hline O sea & 3 & 119 & 316 \\
\hline Vamos & 2 & 22 & 70 \\
\hline Pues & 0 & 22 & 327 \\
\hline Es que & 9 & 41 & 60 \\
\hline Claro & 0.8 & 14 & 34 \\
\hline Hombre & 0 & 1 & 14 \\
\hline
\end{tabular}

* Occurrences per 100.000

Table 1 shows the occurrences of the above-described seven markers in the three different corpora under study. The figures included in this table ac- 
count for the occurrence of these units as HRMs, not as DMs with other functions. Given the different sizes of the corpora, a log-likelihood test has been performed to check the significance of the results ${ }^{3}$. However, for the sake of brevity, it will only be mentioned when considered particularly relevant.

A first tentative look at the results shows, first of all, an overall lower occurrence of HRMs in the TT than in SV, which in turn features less HRMs than CREA. However, the gap between the TT and SV is considerably wider than that between the non-translated corpora. Also, the TT contains less variation in the use of these markers, as it resorts mainly to bueno and does not feature pues or hombre.

\subsection{Bueno}

The case of bueno is the only one in which there is similarity between the TT and SV, the log-likelihood test showing no significant difference between them. Bueno is used in the dubbed script to translate ST HRMs such as well, you know, I mean and other performance phenomena such as repetitions (I-I-I). But more interestingly, the second most common ST unit triggering bueno is $\varnothing$, in other words, bueno is added to the TT without being motivated by any specific ST unit:

Example 1: from Friends, episode 7 - season 1

ST Ross: OK. Here goes. Um, for a while now, I've been wanting to, um....

TT Ross: Vale, allá va. Um, bueno, ya hace mucho tiempo que quiero... verás...

In example 1, um, for a while now could have perfectly been rendered as eh, ya hace mucho tiempo. A closer look at the scene shows, however, an important dubbing constraint at play: although the Spanish utterance is slightly longer than the English one, the speed at which Ross has delivered his hesitant utterances in this scene is considerably higher in Spanish. Unless he drops his speed of delivery considerably for this line, the Spanish dubbing actor will find himself with no text to deliver as Ross is still moving his mouth on screen, thus violating the principle of isochrony, regarded as the most important of all synchronies (Chaume 2004c). An addition must therefore be made to the TT. Bueno is in this case the chosen unit, perhaps in line with a general tendency to add DMs to provide fictional dialogue with a naturalistic effect (Lee and Hsieh 2004, Pérez González 2007). Bueno thus contributes to the (natural) hesitation of the TT, although the choices of verás and um as performance phenomena in Spanish are more questionable. However, the choice of bueno to translate $\varnothing$ is not always caused by dubbing constraints: 
Example 2: from Friends, episode 11 - season 4

ST Phoebe Sr: So, however hard it is to give up this puppy, it would be like a million times harder to give up a child.

TT Phoebe Sr: Así que por muy difícil que te resulte desprenderte de este perrito, bueno, sería un millón de veces más difícil desprenderte de un hijo.

In example 2, the use of bueno is motivated by another specificity of dubbing that is all too often overlooked in favour of the ever-present constraints - the audiovisual leeway. Before Phoebe Sr mentions the word puppy, the camera changes the shot to her back, where it remains until the utterance is finished. Further corroborating the importance of the shooting code in dubbing (Chaume 2004a), the second part of the sentence provides a great deal of freedom in terms of translation. Still, there is no apparent reason why bueno should be added, other than the fact that it is possible to do so. Seeing as Phoebe $\mathrm{Sr}$ is visually nervous in the scene, the translator ${ }^{4}$ introduces a hesitant bueno presumably for a naturalistic effect - not because s/he has to (constraints) but because s/he can (leeway).

On paper, the addition of bueno should not be a problem, given the high occurrence of this marker in both fictional and spontaneous Spanish. However, the naturalness of the TT could be affected if the systematic selection of bueno as a default hesitation marker or privileged carrier of orality (Pavesi 2005) means that no other Spanish HRM is used to express hesitation.

\subsection{O sea}

As for $o$ sea, it shows the biggest difference in occurrence between the dubbed script and the non-translated corpora. Yet, the only four times in which it is used in the TT, such as (3), show what a useful resource it is to convey hesitation in Spanish and especially to translate I mean when acting as a HRM:

Example 3: from Friends, episode 24 - season 1

ST Melanie: You're like the most generous man I ever met, I mean, you're practically a woman.

TT Melanie: Eres el hombre más generoso que he conocido nunca, o sea, prácticamente eres una mujer.

Unfortunately, whereas I mean can be heard once every three minutes in the $\mathrm{ST}$ and $o$ sea once every six minutes in SV, the TT only resorts to o sea once every six hours (that is, once every 12 episodes), which suggests that it is far from being used systematically as a tool to convey hesitation. Furthermore, an analysis of the translation of I mean in the TT shows that in 
$60 \%$ of the cases it has been omitted altogether and in $20 \%$ of the times it has been translated as en fin or verás, which are DMs but which, as will be explained below, do not convey hesitation.

\subsection{Pues}

As for pues, it is absent from the TT, not very recurrent in SV and yet the most common HRM in CREA. This is indeed the biggest gap between the otherwise fairly similar SV and CREA, which suggests that in this case not only the translational factor but also the fictional factor might have an influence on the use of this HRM. The following example from CREA may shed some light on this:

\section{Example 4: from CREA}

TT Entonces tenía este, esta perra, pero como ella hacía guardias y no la podía cuidar, y estos perros, pues..., necesitan, pues... eso, una persona que esté con ellos...

BT so she had this this dog, but since she was on call and couldn't look after her, and these dogs, pues...they need, pues...like, a person to be with them...

As illustrated in (4) and as described by Stenström (2006), mid-sentential hesitant pues tends to co-occur with performance phenomena, especially unfilled pauses. Given the time constraints at play in a scripted discourse such as that of a sitcom (Pavesi 2005), it is only normal that instances of hesitation with pues and unfilled pauses (a particularly time-consuming and thus non fiction-friendly performance phenomenon) may become less recurrent both in translated and non-translated sitcoms.

\subsection{Vamos, es que, claro and hombre}

In the case of vamos, the TT shows a clear preference for the traditional lexicalised vamos as an interjection (98\%) to the detriment of the more modern and specialised HRM vamos (2\%), which is however more common in SV and CREA (22\% and 29\% respectively). In any case, the only two occurrences of the HRM vamos in the TT show that it can sometimes translate I mean very appropriately to convey hesitation. As for es que, it presents a slightly different case. It is more restrictive, given that it fulfils the pragmatic function of justification as well as hesitation and doubt. Yet, even though the TT does not resort to it as often as the non-translated corpora, it features as the second most common HRM in the dubbed script and it seems to successfully play both roles:

Example 5: from Friends, episode 10 - season 1 
ST Fun Bobby: Hey, sorry I'm late, but my, uh, grandfather, he died about two hours ago (...).

TT Bobby el divertido: Hola, cariño, siento llegar tarde, pero, es que, uh, mi abuelo, ha muerto hace un par de horas (...)

Finally, claro and hombre offer a possible translation solution for instances of quick filled pauses used by speakers to stop briefly before resuming their message. These pauses are indeed much shorter than the unfilled and filled pauses that usually co-occur with pues, which makes these two markers much more fiction-friendly than pues and especially useful for the translation of the ST. Claro emerges as a possible natural translation for you know (example 6), not only because you know is often used as a quick filled pause, but also because, just like claro, it places emphasis on shared knowledge (Schiffrin 1987). As for hombre, it is absent from the TT and very rare in SV, but its occurrence in CREA (7) suggests that it is also a very useful HRM, not least because the friendly connotation attached to this marker (Martín and Portolés 1999) could provide the TT with a certain familiarity that has all too often been found to be absent in the TT (Romero Fresco 2006):

Example 6: from Friends, episode 5 - season 1

ST Ross: Apparently, they're attracted to the dryer sheets, and, you know, they're goin' in fine, but they're comin' out all.... fluffy.

TT Ross: Por lo visto, se sienten atraídas por la secadora y, claro, entran bien, pero salen un poco... despeinadas.

\section{Example 7: from CREA}

TT (...) llega un momento en que estás ahí metido en una isla (...) y llega un momento que te agobias, pero, hombre, si no hay otra salida, pues (...) te vas para allí y punto.

BT there's a time when you're stuck there in an island and you can't hack it, but, hombre, if there's no other way out, then you just gotta go there

Finally, with regard to the above-mentioned issue of co-occurrence (i.e. the fact that es que, claro and hombre tend to co-occur with connectors indicating cause, consequence or objection), SV and CREA seem to paint once again a more varied landscape than the TT, which features only two (pero es que and y claro) of the fourteen combinations found in the non-translated corpora:

Table 2: Most recurrent units preceding es que, claro and hombre in the three corpora* 


\begin{tabular}{|c|l|c|c|c|}
\cline { 3 - 5 } \multicolumn{2}{c|}{} & TT & SV & CREA \\
\hline \multirow{4}{*}{ Es que } & Pero & 12 & 58 & 44 \\
\cline { 2 - 5 } & Que & 0 & 25 & 20 \\
\cline { 2 - 5 } & Si & 0 & 38 & 15 \\
\cline { 2 - 5 } & Porque & 0 & 6 & 15 \\
\cline { 2 - 5 } & Es que & 0 & 14 & 4 \\
\cline { 2 - 5 } & Pues & 0 & 1 & 3 \\
\hline \multirow{4}{*}{ Claro } & Y & 1 & 9 & 19 \\
\cline { 2 - 5 } & Pero & 0 & 4 & 12 \\
\cline { 2 - 5 } & Porque & 0 & 0 & 2 \\
\cline { 2 - 5 } & Es que & 0 & 3 & 7 \\
\hline \multirow{3}{*}{ Hombre } & Y & 0 & 0 & 1 \\
\cline { 2 - 5 } & Pero & 0 & 0 & 1 \\
\cline { 2 - 5 } & Porque & 0 & 0 & 1 \\
\cline { 2 - 5 } & Es que & 0 & 0 & \\
\hline
\end{tabular}

\subsection{En fin and verás: two unnatural HRMs used in the TT:}

To conclude, the qualitative analysis of the TT reveals a rather surprising finding: the appearance of two further DMs, en fin and verás, which are not regarded in the literature as HRMs (hence their absence from table 1) and yet are used as the second and third most recurrent HRMs in the TT.

En fin is regarded in the literature as a summarising marker (Martín and Portolés 1999) used in colloquial conversation to present a summary or a conclusion of what has been said. When this previous utterance is a digression from the main topic of the conversation, en fin is used to resume this topic (Flores Acuña 2001), hence its similarity to the resumptive DM anyway (Ferrara 1997). Although Flores Acuña (2001) does point out that en fin may be used to convey doubt, she also explains that this only occurs in very particular cases in which the speaker attempts to introduce a conclusion but fails to do so. The use of en fin as a HRM is thus a marginal one, as proved by its low frequency in SV and CREA ( 0.4 and 0.6 respectively, i.e. $4.4 \%$ and $5.5 \%$ of the total occurrences of en fin). The TT offers a completely different picture. The frequency of en fin as a HRM in the TT is 57.7 , that is, $56.2 \%$ of the total occurrences of en fin. As explained above, en fin is the second most common translation of the HRM I mean in the TT, the first one being the omission. Both strategies are present in (8):

Example 8: from Friends, episode 19 - season 4

ST Ross: I mean, why not? I mean, I mean, why not?

TT Ross: ¿Por qué no? En fin, ¿por qué no? 
As for verás, it is even more striking, since it is more recurrent than en fin as a HRM in the TT (60.6) but it does not feature as such in the literature or in the non-translated corpora included here. As a matter of fact, only brief references in passing have been found about this DM (Beinhauer 1929, Briz 1998), all of which describe it as an attention-getter, that is, a DM used by the speaker to draw attention to what is being said (Romero Trillo 1997). The analysis of verás in CREA shows, however, that this is a formal marker. As such, it is not used in colloquial conversation but in exchanges in which the participants do not know each other (or at least are not close) and are separated by a considerable age difference. Its use as an attentiongetter in the TT thus adds formality to the dubbed script. However, what is relevant to the present study is that, in the majority of cases, verás acts in the TT as a HRM to translate common English HRMs such as well, you know, uh/um or I mean (it is the third most common translation of this marker) or even hesitation phenomena such as repeats. Being as it is a formal attention-getter, its use in hesitation may be regarded as downright unnatural. In example 9, for example, the ST features Paul stuttering in a tense situation (an intimate confession) as he uses performance phenomena. Instead, the TT provides him with a much more confident attitude. Um and $u h$ are omitted and the repeat (ever-ev-ever) is turned into verás, with which Paul no longer hesitates but formally draws the attention of the addressee to what he is about to say:

Example 9: from Friends, episode 1 - season 1

ST Paul: Well, ever-ev-ever since she left me, um, I haven't been able to, uh, perform sexually.

TT Paul: Bueno, verás, desde que ella me abandonó, yo no he conseguido volver a funcionar sexualmente.

Most importantly, verás is often added to the TT, like bueno, as a (unnatural) privileged carrier of orality to convey hesitation in instances of $\mathrm{AV}$ leeway:

Example 10: from Friends, episode 7 - season 4

ST Chandler: It's-it's about Kathy. Um, I like her. I like her a lot, actually.

TT Chandler: Es-es acerca de Kathy. Bueno, verás, me gusta. Me gusta cantidad, de hecho.

In this example, a one-to-one translation of um as bueno would have fitted perfectly in the actor's lips, but the limited freedom that characterises isochrony (AV leeway) allows the addition of a two-syllable word such as verás without losing much synchrony. Once again, this instance of leeway 
shows how the translator adds a HRM not as an imposition of AV constraints but as a personal choice, risking a certain loss of synchrony, presumably to add a naturalistic effect. The problem is that, unlike in the case of bueno, verás only makes the TT more unnatural.

\section{Conclusions}

The results obtained in the present study reveal a number of unnatural features in the Spanish dubbing language used to convey hesitation in the translation of Friends. First of all, the translator seems to choose three privileged carriers of orality to express hesitation (bueno, en fin and verás), two of which (en fin and verás) may be regarded as unnatural, as they are used with a different value in both spontaneous conversation and nontranslated prefabricated conversation. Hesitation also seems to be considerably less prominent in the dubbed script than in the ST, as illustrated by the fact that the most common translation strategy for the HRM I mean is the omission (followed by en fin and verás). Furthermore, the use of the above-mentioned three markers brings about a worrying lack of variation in the TT, given the absence or low occurrence of other HRMs that are very common in SV and CREA, such as o sea, vamos, pues, es que etc. This is also reflected in the lack of combinations of these markers with other units with which they often co-occur in spontaneous conversation. In this sense, the TT also proves very conservative, resorting to the most traditional choices (bueno as a HRM, vamos as an interjection) as opposed to more modern hesitation markers (hombre, claro) that could add much-needed familiarity to the dubbed dialogue. Interestingly enough, the use of HRMs in the dubbed script resembles that of non-native speakers (high occurrence of bueno and es que, rare use of frequent but non-transparent markers such as o sea and pues, incorrect use of some markers) and is more monotonous, less colorful, less idiomatic and, overall, less natural than in native Spanish spontaneous colloquial dialogue.

On a more general note, this study suggests that placing the focus on the specificity of AVT may be more useful than placing it on its constraints. Firstly, it is this approach that allows the consideration of naturalness, a key concept that has been repeatedly overlooked in the literature. Slippery and subjective as it may seem, naturalness in dubbing can be tackled empirically if combined with corpus-based studies on colloquial conversation, resulting in mutually beneficial results (in this case, the benefit for the latter would be specific data about the use and occurrence of HRMs in prefabricated and spontaneous conversation). Secondly, the focus on the specificity of dubbing allows the consideration of constraints under a new light. They have an undeniable impact on the translation of an audiovisual text, but they co-exist with instances of leeway that are just as revealing, if not more, about key aspects such as the translator's purpose. The corpus analysed, for example, shows how the translator's effort to provide the 
dubbed dialogue with a naturalistic effect adding a number of privileged DMs is thwarted by the unnatural nature of some of these markers. In any case, the examples included in the qualitative analysis of the constraints suggest that it is possible, at least when it comes to HRMs, to achieve synchronised natural dialogue or, taking up Myer's description (1973), to synch and swim naturally on the side.

Yet, a number of questions still have no answer: how significant are the results of HRMs as compared to those of other DMs? And as compared to key units of colloquial conversation other than DMs? Indeed, having identified the problem, chosen the methodology and obtained the first results, future research could be focused on the study of, for example, interactive markers such as attention-getters, or metadiscourse markers such as transitional markers, as well as other key features of colloquial conversation in order to achieve a more thorough characterisation of dubbing language.

Finally, there is another problem that remains unsolved, namely the cause or origin of the lack of naturalness found in the TT. The fact that the gap between the TT and SV is considerably bigger than that between SV and CREA suggests that, with the exception of pues, it is the translational factor and not the fictional factor that has the greatest impact on the naturalness of the TT. Yet, none of the translational factors mentioned in section 4 seems to pose difficulties for the use of natural HRMs in the TT: the ST markers are those found in spontaneous conversation (and thus natural), the translator seems to strive for naturalness and the constraints provide enough scope to resort to natural markers. Where does this lack of naturalness come from then? Although a possible answer may lie in the suspension of linguistic disbelief (Romero Fresco forthcoming), this question merits, as do the other posed in this paragraph, its own study, and must thus remain open, in need of a future answer.

\section{Bibliograpy}

Baumgarten, Nicole (2005). The Secret Agent: Film dubbing and the influence of the English language on German communicative preferences. Towards a model for the analysis of language use in visual media. PhD Thesis. University of Hamburg.

Beinhauer, Werner (1929) (1964). El español coloquial. Madrid: Gredos.

Berger, Arthur Asa (1990). Scripts. Writing for Radio and Television. Newbury Park, London, New Delhi: Sage Publications.

Biber, Douglas, Stig Johansson, Geoffrey Leech, Susan Conrad \& Eward Finegan (1999). Longman Grammar of Spoken and Written English. Harlow: Longman.

Briz, Antonio (1998). El español coloquial en la conversación. Barcelona: Ariel.

Brown Gillian \& George Yule (1983). Teaching the Spoken Language. Cambridge: Cambridge University Press.

Chaume, Frederic (2004a). Cine y traducción. Madrid: Cátedra.

Chaume, Frederic (2004b). "Discourse Markers in Audiovisual Translating". Meta 49(4), 843-855.

Chaume, Frederic (2004c). "Synchronization in dubbing: A translational approach". P. Orero (ed.) Topics in Audiovisual Translation. Amsterdam/Philadelphia: John Benjamins Publishing Company, 35-53.

Chaume, Frederic (forthcoming). "Quality standards in dubbing: a proposal". To appear in Cadernos de Traduçao. 
Christl, Joachim (1996). "Muletillas en el español hablado". Thomas Kotschi, Wulf Oesterreicher \& Klaus Zimmermann (eds.) (1996). El español hablado y la cultura oral en España e Hispanoamérica. Vervuert Verlag, Frankfurt am Main, 117-146.

Coates, Jennifer (1996). "The negotiating of coherence in face-to-face interaction: some examples from the extreme bounds". Morton Ann Gernsbacher \& Talmy Givón (eds). Coherence in spontaneous text. Amsterdam/Philadelphia: John Benjamins, 41-58.

Cortés Rodríguez, Luis (1991). Sobre conectores, expletivos y muletillas en el español hablado. Málaga: Editorial Librería Ágora.

España Villasante, Margarita (1996). "Aspectos semántico-pragmáticos de la construcción es que en español”. http://www.ucm.es/BUCM/revistas/ fll/ 02122952/articulos/DICE9696110129A.PDF, (last visited on 5 September 2007).

Ferrara, Kathleen (1997). "Form and function of the discourse marker anyway: implications for discourse analysis". Linguistics 35, 343-378.

Flores Acuña, Estefanía (2001). Los diccionarios bilingües como herramientas de referencia para estudiantes avanzados de español como lengua extranjera. Chile: Universidad de Chile, Facultad de Filosofia y Humanidades.

Fox Tree, Jean \& Josef Schrock (2002). "Basic meanings of you know and I mean". Journal of Pragmatics 34 (6), 727-747.

Fuller, Janet (2003). "The influence of speaker role on discourse marker use". Journal of Pragmatics $35,23-45$.

Gottlieb, Henrik (2006). “Constraints, Conventions and Conflicts in Screen Translation'. Paper presented at MuTra 2006 - Audiovisual Translation Scenarios (University of Copenhagen, 1-5 May 2006)

Gregory, Michael \& Suzanne Carroll (1978). Language and situation: language varieties and their social contexts. London: Routledge.

Herbst, Thomas (1987). "A pragmatic translation approach to dubbing”. EBU Review, Programmes, Administration, Law 38, 6, 21-23.

Hernández García, Carmen (1997). "El va en español, un caso de interferencia del catalán”.Espéculo 6. http://www.ucm.es/info/especulo/numero6 /c_hernan.htm. (last visited on 2 September 2007).

Huerta, Miguel Ángel (2005). "Las sitcom en televisión. La verdad, el dolor y la risa inteligente". Revista Universitaria de la Pontificia Universidad Católica de Chile 89, 14-18.

Kelly, Robin (2003). "How a US Sitcom is Made". Writing for Performance. http://www.robinkelly.btinternet.co.uk/ussitcom.htm. (last visited on 30 August 2007).

Lam, Phoenix (2006). "Contextual variation in the use of discourse particles: The case of well.". Paper presented at Third Inter-Varietal Applied Corpus Studies (IVACS) Group International Conference on Language at the Interface (University of Nottingham 23-24 June 2006).

Lee, Beryl Chinghwa \& Chin-Jung Hsieh (2004). "Discourse marker teaching in college conversation classrooms". http://www2.cmu.edu.tw/ cmcgen/69.pdf . (last visited on 5 August 2007).

Leech, Geoffrey \& Jan Svartvik (1994). A Communicative Grammar of English. Second Edition. London: Longman.

Lindqvist, Helena (2005). "El desarrollo de marcadores discursivos en español L2 en el transcurso de un semestre de estudios en España”. Proceedings of XVI Congreso de Romanistas Escandinavos.

Martín, María Antonia \& José Portolés (1999). "Los marcadores del discurso". Ignacio Bosque \& Violeta Demonte (eds). Gramática Descriptiva de la Lengua Española 3. Madrid: EspasaCalpe, 4051-4213.

Mattsson, Jenny (2007). "Linguistic Variation in Subtitling.The subtitling of swearwords and discourse markers on public television, commercial television and DVD”. MuTra 2006 Audiovisual Translation Scenarios: Conference - Proceedings. http://www.euroconferences.info/proceedings/ 2006_Proceedings/2006_Mattsson_Jenny.pdf. (last visited on 15 September 2007).

Mayhew Archer, Paul (2005). "Interview for Sitcom Workshop". Writing for Performance. http://www.robinkelly.btinternet.co.uk/c41.htm. last visited 07 September 2007).

Mayoral, Roberto, Dorothy Kelly and Natividad Gallardo (1988). "Concept of constrained translation. Non-linguistic perspectives of translation”. Meta 33, 356-367.

Meehan, Teresa (1991). "It's like, 'what's happening in the evolution of like?: a theory of Grammaticalization". Kansas Working Papers in Linguistics 16, 37-51.

Myers, Lorna (1973). “The Art of Dubbing”. Filmmakers Newsletter 6, 56-58. 
Nye, Simon, Fred Barron \& Micheal Jacob (2005). "Writing comedy". Get Writing. http://www.bbc.co.uk/dna/getwriting/module28p. (last visited on 6 September 2007).

Onions, Charles Talbut. (ed.) (1964). The Shorter Oxford English Dictionary. Oxford: Clarendon.

Pavesi, Maria (2005). "Spoken language in film dubbing: target language norms, interference and translational routines". Paper presented at Between Text and Image. Updating Research in Screen Translation (University of Forlì 27-29 October 2005).

Pawley, Andrew \& Frances Syder (1983). "Two puzzles for linguistic theory: nativelike selection and nativelike fluency". Jack Richards \& Richard Schmidt (eds). Language and Communication 7 (1). London: Longman, 191-226

Pérez Gonzalez, Luis (2007). "Appraising Dubbed Conversation. Systemic Functional Insights into the Construal of Naturalness in Translated Film Dialogue". The Translator 13 (1).

Pfister, Manfred (2001). Das Drama. Munich: Wilhelm Fink Verlag (UTB).

Porroche Ballesteros, Margarita (1996). "Las llamadas conjunciones como elementos de conexión en el español conversacional". Thomas Kotschi, Wulf Oesterreicher \& Klaus Zimmermann (eds). El español hablado y la cultura oral en España e Hispanoamérica. Vervuert Verlag, Frankfurt am Main, 71-93.

Porroche Ballesteros, Margarita (1998). "Sobre algunos usos de que, si y es que como marcadores discursivos". María Antonia Martín Zorraquino \& Estrella Montolío Durán. (coords.). Los marcadores del discurso. Teoría y análisis. Madrid: Arco Libros, 229-242.

Romero Aguilera, Laura (2006). "La gramaticalización de verbos de movimiento como marcadores del discurso: el caso de vamos". Res Diachronicae 5, 46-56. http://home.pages.at/resdi/Numeros/Numero5/Parte2_Art4.pdf. (last visited on 1 September 2007).

Romero Fresco, Pablo (2006). "The Spanish Dubbese - A case of (un)idiomatic Friends". Journal of Specialised Translation 06. http://www.jostrans.org/ issue06/art_romero_fresco.php. (last visited on 13 September 2007).

Romero Fresco, Pablo (forthcoming). "Naturalness in the Spanish Dubbing Language: A case of not-so-close Friends". To appear in Meta.

Romero Trillo, Jesús (1997). "Your attention, please: Pragmatic mechanisms to obtain the addressee's attention in English and Spanish conversations". Journal of Pragmatics 28, 205 221

Schiffrin, Deborah (1987). Discourse markers. Cambridge: Cambridge University Press.

Schwenter, Scott (1996). "Some reflections on o sea: A discourse marker in Spanish". Journal of Pragmatics 25, 855-874.

Sinclair, John (ed.) (1995). Collins Cobuild English Dictionary. Glasgow: HarperCollins Publishers.

Stenström, Anna-Brita (2006). "The Spanish discourse markers o sea and pues and their English Correspondences". Karin Aijmer \& Anne-Marie Simon-Vandenbergen (eds). Pragmatic Markers in Contrast. Amsterdam: Elsevier, 155-172.

Titford, Christopher (1982). "Sub-titling: constrained translation". Lebende Sprachen 27(3), 113-116.

Vigara Tauste, Ana María (1992). Morfosintaxis del español colloquial. Madrid: Gredos.

Warren, Beatrice (2004). "A model of idiomaticity". Paper presented at Ninth Nordic Conference for English Studies (NAES 2004) (Aarhus, Denmark 27-29 May 2004).

1 Given that, as will be described in 4, the audiovisual text is regarded here as a semiotic construct comprising several signifying codes (shooting code, sound code, paralinguistic code, etc.) (Chaume 2004a), its naturalness cannot be assessed only on the basis of the linguistic code. However, this is usually the only code the translator can alter, which is why it has been chosen as the focus of this article.

2 For a more detailed account of these features, see Romero Fresco (forthcoming)

3 The log-likelihood test is one of several methods available to ascertain whether the differences found between two corpora of different sizes are significant or not. If the result of the loglikelihood test is greater than 6.63, the probability of the result - i.e. the difference between the two corpora - happening by chance is less than $1 \%$. A description of this test and a loglikelihood calculator can be found at the University of Lancaster website (http://bowlandfiles.lancs.ac.uk/courses/ahaw-nscl/108_4.htm)

4 It should be noted that any reference to the translator in this article is actually a reference to anybody involved in the dubbing of the ST, including the translator, the dialogue writer (in charge of the synchronisation an adaptation of the text provided by the translator), the dubbing director and the dubbing actors. 